Version of 15.viii.13, bibliography updated 3.i.15. American spelling \& punctuation.

Transliteration after IJMES standard. ` for 'ayn, ’ for hamza.

\title{
BASRA AND KUFA AS THE EARLIEST CENTERS OF ISLAMIC LEGAL
}

\section{CONTROVERSY}

by Christopher Melchert

University of Oxford

The starting point of this essay is an observation by Patricia Crone: ${ }^{1}$

The most important differences (in terms of substantive law) are not those between Sunnīs and non-Sunnīs, but rather those between the Kufan and Basran schools on the one hand and the Medinese and later schools on the other. If one compares the positions of the eight surviving schools on fundamental issues such as whether a person can bequeath more than a third of his estate, whether nonagnatic and non-Qur'ānic relatives (dhawu'l-arhām) can inherit, whether there is such a thing as contractual wala' ' and whether qasāma is a defensive or accusatory procedure, one finds that the Hanafìs, the Ibādīis and the three Shī ite schools regularly form one bloc, while the Mālikīs, Shāfi' ’’’s and Hanbalīs form another. The first five perpetuate the legal tradition of the old Iraqi schools.

The hypothesis tested in the present contribution is whether not Kufa/Basra and Medina but Kufa and Basra were originally the two rival centers of early Islamic legal controversy, with Medinese law a subsequent development based on back projection of Basran positions.

\section{REGIONAL SCHOOLS OF LAW}

Joseph Schacht described al-Shāfi'ī (d. 204/820) as arguing against "the ancient schools." The three great geographical centers as they appear in al-Shāfi' ’’’s works are Iraq, the Hijaz, and Syria, Iraq subdivided between Kufa and Basra, the Hijaz between Medina and Mecca. ${ }^{2}$ Writing independently at the same time, Robert Brunschvig inferred the predominance of local traditions

\footnotetext{
${ }^{1}$ Crone, Roman, 23.

${ }^{2}$ Schacht, Origins, 8.
} 
not only from the polemics of al-Shāfi ‘̄ but letters between al-Layth b. Sa`d and Mālik b. Anas. ${ }^{3}$ Schacht conceived of inter-regional competition as a principal motor of Islamic legal development: the jurisprudents of one center would trump the argument of those of another by identifying their own rule with a Follower $(t \bar{a} b i\urcorner \mathfrak{\imath})$, the jurisprudents of the other center would respond by identifying their rule with a Companion, finally rules were projected back onto the Prophet himself. ${ }^{4}$ George Makdisi identified three stages in the formation of the schools of law: a regional stage, when jurisprudents were primarily identified with one or another metropolis; a personal stage, when jurisprudents were primarily identified by their loyalty to one predecessor such as Abū Hanīfa or al-Shāfi '̌̀; and a guild stage, when the schools served to form and certify qualified jurisprudents. $^{5}$

Wael B. Hallaq has questioned whether we should speak of regional schools, pointing out that our earliest books of law (with the partial exception of Mālik's Muwațta') normally cite individual authorities, not anonymous local tradition. ${ }^{6}$ It can easily be shown that Hallaq does not discredit any earlier scholar's description of regional schools. No one before him said that a regional school, to exist, must be cited anonymously. Neither did anyone before him assert that the regional schools had clear, enforceable boundaries just like the later guild schools. The point of a guild school is that it has enforceable boundaries, unlike the groupings that went before. It is also easy to find references to regional schools in the sources cited by Schacht and Brunschvig. For example, when al-Shāfi' `’’s anonymous interlocutor (probably al-Shaybānī) refers to the

\footnotetext{
${ }^{3}$ Brunschvig, "Polémiques," esp. 379-87. The earliest appearance of these letters, to my knowledge, is in Fasawī, Ma`rifa, 1:687-97.

${ }^{4}$ Schacht, Origins, esp. part 2, chapter 3, "The conflict of doctrines as reflected in the growth of traditions," $152-63$.

${ }^{5}$ Makdisi. “Tabaqāt-Biography,” 389-92.

${ }^{6}$ Hallaq, "From Regional?” passim.
} 
doctrine of the muftis of his time, al-Shāfi ${ }^{1}$ immediately asks him about those of the various centers (buldān). He starts with Kufa, where he points out that Ibn Abī Laylā disagrees, then moves to Basra. A little further on, the interlocutor refers to "your aṣhāb the Meccans."7 This is not a picture of myriad personal schools that will be shaken down to the four or five guild schools in time, nor the way disagreements are listed in the guild period. The legal sources on which Schacht and Brunschvig relied are confirmed by Ibn al-Muqaffa`(d. 142/759-60?), who describes disagreement between and within regions. The main cleavage he points out is between the people of Iraq and the people of the Hijaz, although he also mentions disagreement within cities. ${ }^{8}$ Besides the correspondence of Mālik and al-Layth b. Sa`d cited by Brunschvig, we have a letter supposedly written by Mālik to the caliph, explaining why it would not be feasible for him to produce a book to be imposed on all the regions, since they were already used to their different ways. ${ }^{9}$ (The foregoing paragraph is not offered as a thorough refutation of Hallaq's article, rather a suggestion of why I think it is safe to proceed with a study of regional schools.) As for defining and documenting regional doctrine, Josef van Ess analysed isnād trees, along with other evidence, to see where particular theological doctrines were current. ${ }^{10}$ Michael

\footnotetext{
${ }^{7}$ Shāfi `̄, Ikhtilāf al-ḥadīth, Umm, 7:336-8 10:277-8 (the numbers refer to two different editions). Al-Shāfi `̄i is still classified among the jurisprudents of Mecca by Nasā'̀̄, Tasmiya, Majmū' at rasā' 'il, 8 32; Bukhārī, Du 'afā', 124. The special solicitude of al-Shāfi ${ }^{1} 1$ for the tradition of Mecca is remarked by Brunschvig, "Polémiques,” 379. It has recently been documented by Yahia, Šăfi $\bar{\imath}, 94-106$.

${ }^{8}$ Ibn al-Muqaffa', Risāla, 353. Schacht remarks this epistle briefly, Origins, 95.

${ }^{9} \mathrm{Ibn}$ Sa`d, al-Tabaqāt al-kubrā: al-qism, 440-1. Additional and variant quotations reviewed by Dutton, Origins, 192, n. 86 .

${ }^{10}$ Josef van Ess, Zwischen; e.g. finding that one predestinarian hadith report had transmitters concentrated in Kufa and Medina, 99. Van Ess may be credited with inventing what Motzki calls the isnād-cum-matn technique of identifying particular variants with particular transmitters, although without giving it a name.
} 
Cook located longest-lasting opposition to the writing of hadith in Basra. ${ }^{11}$ Their method is to look up where the men in an isnād were active. Our biographical directories of traditionists, if not arranged regionally to start with, pay considerable attention to geography; hence Ibn Hajar, synthesizing many early biographical collections, provides some indication of date, even so general as the caliphal reign in which someone died, for only about 40 percent of all the men in the Six Books, but an indication of place for 70 percent. $^{12}$

This present essay is especially concerned with the relation of the different schools to one another. Joseph Schacht spoke of Islamic jurisprudence (that is, "the first theorizing and systematizing activities which were to transform Umaiyad popular and administrative practice into Muhammadan law") as originating in a single centre[center], mainly Iraq. ${ }^{13}$ Writing at about the same time, Robert Brunschvig described it as being born, in its classical sense, in Kufa. ${ }^{14}$ Schacht found that Medinese positions continually looked like responses to Kufan. ${ }^{15}$ A complication is borrowing between one center and another. "A favourite device in the creation of counter-traditions," according to Schacht, "consists of borrowing the name of the main authority for, or transmitter of, the opposite doctrine."16 This accounts for the many instances in which someone is cited on both sides of a question. An example is whether `Abdallāh b. al-Zubayr pronounced the basmala aloud (on which question more below). Najam Haider cites a quotation by which he did, directly opposed by another by which he and his

\footnotetext{
${ }^{11}$ Cook, “Opponents,” esp. 446-9, 455-8, 464-6, 474-5.

${ }^{12}$ More on the problem of where traditionists were active in Melchert, "Life."

${ }^{13}$ Schacht, Origins, 222-3.

${ }^{14}$ Brunschvig, "Polémiques," 378.

${ }^{15}$ Schacht, Origins, 188-9, 220, 223.

${ }^{16}$ Ibid., 155.
} 
brother 'Urwa did not. ${ }^{17}$ The hadith report by which he did pronounce it aloud has a solidly Basran chain of transmitters up to Ibn Abī Shayba, whereas the report by which he did not has a Kufan on its lower (more recent) end but then moves to Medinese from the mid-eighth century upwards. After Schacht, then, I would infer that the former hadith report represents Basran doctrine projected onto a prominent Companion, whereas the latter represents Kufan doctrine projected onto at least one of their Basran opponents' authorities. The difficulty is to be met, then, by being wary of reports supported by mixed isnäds that veer from one region to another.

Another complication is evident disagreement within cities, as observed by Ibn al-Muqaffā'. Schacht thought that where Ibn Mas 'ūd was commonly adduced in support of the majority Kufan position, `Alī would often be adduced in support of a minority position; yet it also happened that `Alī would endorse the majority position, Ibn Mas' ūd that of the opposition. He mentions Sufyān al-Thawrī (d. Basra, 161/777?) as an example of someone identifiably Kufan in his doctrine, yet often opposed to what became the Hanafi position. ${ }^{18}$ Al-Shāfi î̀'s Kitāb al-Umm includes two shorter works just on disagreement within Kufa, Ikhtilāf Abì Hanīfa wa- 'bn Abì Laylā and Ikhtilāf 'Alī wa- 'Abdallāh b. Mas `ūd, another work on his own disagreements with Mālik (Ikhtilāf Mālik wa-l-Shāfi ‘̂̀), in which he frequently accuses Mālik of falsely claiming a Medinese consensus behind his own position when in fact there is Medinese disagreement.

Juynboll has proposed another particular method: ${ }^{19}$

\footnotetext{
${ }^{17}$ Haider, "Basmalah," 497, isnād no. 116. This is to be found in Ibn Abī Shayba, Mușannaf, k. al-șalāt 237, man kāna yajharu bihā, ed. J\&L, 2:371, no. 4175. The opposing hadith report is at Ibn Abī Shayba, Muṣannaf, k. al-șalāt 236, man lā yajharu bi-bi’sm Allāh, ed. J\&L, 2:369, no. 4157.

${ }^{18}$ Schacht, Origins, 240-2.

19 Juynboll, “Some Notes," 311.
} 
Mālik $\rightarrow$ Nāfi' $\rightarrow$ Ibn `Umar $\rightarrow$ Prophet strands were simply attached by Mālik and later traditionists, such as many of the great collectors like Ibn Hanbal, Buhārī, and Muslim, to legal material that originated outside Medina and without which Medina's legal system looked incomplete, as if it lagged behind the systems developed elsewhere. In other words, the Medinan jurists thus incorporated that foreign legal material into their already existing system, supporting it with their own renowned strand to make it truly «Medinan».

This sort of back projection will be much harder to detect than citing the opponents' authorities.

It will be a reason Juynboll systematically distrusted "single strands," akhbār al-āhād in the technical language of medieval jurisprudents. It is one more warning not to presume that Prophet (and Companion) reports supported by unmixed, single-region isnāds actually do go back to the earlier seventh century.

The hypothesis tested in the present contribution is whether not Kufa/Basra and Medina but Kufa and Basra were originally the two rival centers of early Islamic legal debate, with Medinese law a subsequent development based on back projection of Basran positions. This hypothesis first suggested itself to me when I studied the problem of whether women should be allowed to go to the mosque and to lead prayers. At the level of the Followers, I found opposition to women's activity concentrated in Kufa, its defense in Basra, and then Medinese defense of it citing Companions. ${ }^{20}$ The next year, I proposed some further examples in an unpublished convention paper. ${ }^{21}$ I put the case most strongly in a study of the judicial oath in Islamic law, although conceding that this particular problem offered only weak evidence for it. ${ }^{22}$ A study of eighth-century polemics over public baths found doubts about them concentrated in Basra and their defense in Kufa, although with dissenting minorities in both centers. Again, Medinese reports expressed doubts, in line with the prevailing Basran opinion, but going back to

\footnotetext{
${ }^{20}$ Melchert, "Whether," esp. 60-1.

${ }^{21}$ Idem, "Muṣannaf."

${ }^{22}$ Idem, "History," esp. 324-5.
} 
Companions and the Prophet. ${ }^{23}$ On Schacht's thesis of progressive back-projection, Medinese citations of Companions and the Prophet would presumptively represent improvements on earlier Basran arguments.

\section{REGIONAL POSITIONS IN THREE EARLIER STUDIES}

Yasin Dutton and I have both written about the salutation at the end of the ritual prayer. Dutton first goes over in detail the hadith cited in the Muwațta' of Mālik, the Mudawwana of Saḥnūn, al-Hujja 'alā ahl al-Madīna of al-Shaybānī, al-Umm of al-Shāfì' al-Razzāq and Ibn Abī Shayba. Dutton thinks his evidence is incompatible with the theories of Goldziher and Schacht. First, earlier sources (above all, `Abd al-Razzāq and Ibn Abī Shayba, not published when Schacht was writing) cite the Prophet, Companions, and Followers, whereas later sources concentrate exclusively on the Prophet. Secondly, "the majority of the ahāait th included by the later collectors have antecedents in the earlier material, both in terms of isnād and actual contents: that is, they do not represent something new, and thus by implication fabricated, but rather are recycling or reorganizations of older material." ${ }^{24}$ I think nothing of the sort: that Islamic law before al-Shāfi ${ }^{1} \overline{1}$ was not founded mainly on the remembered example of the Prophet is exactly Goldziher's and Schacht's main thesis, while Dutton's later collections illustrate very well the improvement, backward growth, and spread of isnāds of which Schacht complains. ${ }^{25}$ For example, as Dutton observes, Ibn Māja (or Mājah) quotes a prophetic hadith report through `Ammār b. Yāsir in favor of two salutations, whereas al-Shaybān̄̄, `Abd al-Razzāq, and Ibn Abī Shayba report rather 'Ammār b. Yāsir's own practice of saluting twice. ${ }^{26}$

\footnotetext{
${ }^{23}$ Idem, "Public."

${ }^{24}$ Dutton, "Innovation," 170-1.

${ }^{25}$ The three terms appear together at Schacht, Origins, 166.

${ }^{26}$ Dutton, "Innovation," 171.
} 
What is new is the attribution to the Prophet himself, which it seems to me has a high probability of being fabricated, convenient as it is to the orthodoxy of Ibn Māja's own time.

I will make two methodological points. First, Dutton states that the Hanafi, Shāfì i, and Hanbali schools all call for saluting twice, whereas the Māliki school calls for only a single salutation in some circumstances. ${ }^{27}$ Actually, this is somewhat of a simplification. As Dutton himself points out, al-Shāfi ${ }^{\top} \overline{1}$ appears to hold only the first salutation necessary, the second being merely recommended. ${ }^{28}$ Disagreement is reported within both the Shāfi $i$ and Hanbali schools as to whether a second salutation is strictly required, while four different opinions are ascribed within the school to Mālik. ${ }^{29}$ (The Hanafi school holds them both recommended, not required.) I think the point is worth raising to show that disagreement within a school is fairly normal, in the guild period as in the regional. Some critics have suggested that it is futile to identify regional schools unless one can point to evident unanimity, a criterion that would equally disallow us to speak of a Shāfi ’i or Hanbali school. ${ }^{30}$ Secondly, Dutton does not look at the Musnad of Ahmad b. Hanbal. My own search of the Musnad came up with 25 hadith reports treating the number of salutations. They are all prophetic, unsurprisingly, and they all describe two salutations. Fifteen of them are Kufan, none is Basran all the way back to a Companion, most of the rest are Medinese or mainly so. Would it have made any difference to his analysis? Probably not: the hadith here falls into principal groups of hadith identified by Dutton from elsewhere. As for

\footnotetext{
${ }^{27}$ Dutton, “Innovation,” 148.

${ }^{28}$ Shāfi `ī, Umm, 1:106 2:279 ; Dutton, “Innovation,” 167fn.

${ }^{29}$ Melchert, “Concluding,” 398-9 (Shāfì i opinions); Mardāwī, Inșāff, 2:64 (Hanbali); Melchert, “Concluding,” 399400 (Māliki).

${ }^{30}$ E.g., Hurvitz, “Schools," esp. 44-5; Katz, Body, index, s.v. "regional schools”; also Hallaq, "From regional,” e.g. where the occurrence of disagreement within Medina is offered as evidence that no Medinese school existed (6).
} 
geography, it does imply that Kufans were extraordinarily busy with citing prophetic precedent for what was presumably the Kufan position.

Dutton lists Companion and Follower positions as reported by his early sources. Companion positions run eight-to-six in favour of one salutation, five-to-three if we eliminate contradictory reports. Follower positions run fourteen-to-twelve in favor of one salutation, eleven-to-nine if we eliminate contradictory reports. This is important to his case for one salutation as the dominant practice before pressure developed to follow Prophet hadith. If we classify the Followers geographically, the 14 Followers quoted in favor of one salutation turn out to include six Kufans, four Basrans, three Medinese, and one Meccan; if we eliminate persons quoted on both sides, five Kufans, three Basrans, and three Medinese. The twelve Followers quoted in favor of two salutations turn out to include nine Kufans and one each of Basrans, Meccans, and Medinese; if we eliminate persons quoted on both sides, eight Kufans and one Medinese. It looks as if, in the early eighth century, Kufa and Medina were divided but leaning toward one, the position in favor of which Basra was united. This seems to strengthen Dutton's case slightly, at least for one salutation as the originally predominant position. It also makes it unsurprising that al-Shāfi '̄̄ should have been able to find so much Medinese Prophet hadith in favor of two, it having long been at least a minority position in Medina. What about citations of the rival center's authorities: will Dutton's figures be further affected if we eliminate mixed isnāds? By some: among Follower reports in favor of one salutation, we are left with three Kufan, two Basran, and three Medinese; in favor of two salutations, six Kufan and one Medinese. Basra still appears to be solidly in favor of one salutation, Kufa and Medina divided, but now the majority position in Kufa seems to be two salutations. This makes it less surprising that two salutations should have prevailed there (and in the Hanafi school to come) in the long term. 
Another particular problem has been analysed by Najam Haider: whether to begin recitation of Q. 1 (al-Fätiha) in the ritual prayer with the words bi-'sm Allāh al-Rahmān al-Rahīm (the basmala) or rather al-hamd lillāh rabb al-'ālamīn. Haider examines the legal literature and finds that the Shâfi i school advocates beginning with the basmala aloud, the Māliki school with al-hamd lillāh, the Hanafi school with the basmala to oneself, then al-hamd lillāh aloud, the Hanbali school with the basmala aloud but with reservations as to whether it is actually a part of the Qur'an. (Within the school, Ahmad is quoted as saying it is not said aloud, is said aloud, is said aloud in Medina alone, is said aloud in supererogatory only. ${ }^{31}$ ) Regional specialization appears if one inspects the hadith cited in support of each of these positions. ${ }^{32}$ As one might expect, al-Shāfì quotes a series of hadith reports in favour of beginning with the basmala aloud through Meccan informants going back to Companions, with three exceptions. ${ }^{33}$ One of these exceptions goes back to Ibn `Abbās without any chain of transmitters (isnād). One goes through the Kufan Sa`ìd b. Jubayr (d. 95/714?); but he fled with his father to Mecca at some point and is said to have derived his text of the Qur'an from Ibn `Abbās, whom he here quotes in favour of counting the basmala an integral part of Q. $1 .{ }^{34}$ The last exception is a hadith report that al-Shāfīì knows about through Sufyān b. 'Uyayna (d. 198/814), a Kufan who transferred to Mecca, going back through Basran transmitters to the report of Anas b. Mālik that the Prophet, Abū Bakr, and 'Umar all started with al-hamd lillāh.

Al-Shāfi`ì interprets away this contrary hadith report as describing what the Prophet, Abū Bakr, and 'Umar did after pronouncing the basmala. 'Abd al-Razzāq and Ibn Abī Shayba

\footnotetext{
${ }^{31}$ Mardāwī, Inșāf, 2:37.

${ }^{32}$ Haider, "To basmalah"; idem, Origins, chapter 3, 57-94.

${ }^{33}$ Shāfì ${ }^{1}, U m m, 1: 93-4$ 2:244-7.

${ }^{34}$ See Jeffery, Materials, 245.
} 
recount various hadith reports through Basran transmitters from Anas in favour of starting with al-hamd lillāh, sometimes omitting the Prophet. ${ }^{35}$ Mālik quotes one of them to support his position of starting with al-hamd lillāh. `Abd al-Razzāq and Ibn Abī Shayba also quote the Companion 'A' 'isha, with a Basran isnād, testifying to the Prophet's beginning with al-hamd lillāh. Two hadith reports testify to Ibn Mas`ūd and Anas' own omission of the basmala. Near the end of the section, we also have two reports of Follower practice: al-Hasan (d. 110/728) and Abū Wā'il (d. ca. 100/718-19) both opened their recitation with al-hamd lillāh rabb al- ālamìn. Al-Hasan was Basran, of course, and the solidly Basran isnād of this report is unsurprising. Abū Wā'il, on the other hand, was Kufan; however, the isnād attached to this report of his prayer is likewise solidly Basran, so it presumably represents the Basrans' citing one of their opponents' authorities.

`Abd al-Razzāq and Ibn Abī Shayba also report hadith in favor not of omitting the baslama but of pronouncing it only to oneself. Each has only one that goes all the way back to the Prophet. Anas, in this version, says, "I prayed behind the Prophet, Abū Bakr, 'Umar, and 'Uthmān. They did not say aloud bi-'sm Allāh al-Raḥmān al-Raḥim."36 They have more hadith from Companions and Followers. Besides examples, there is one definite rule from a Follower, Ibrāhīm al-Nakha`ī: “The imam says silently bi-’sm Allāh al-Raḥmān al-Raḥim, the isti àdha, $\bar{a} \bar{i} n$, and rabbanā laka al-ḥamd." ${ }^{37}$ This has a solidly Kufan isnād down to Ibn Abī Shayba, like some others reporting Companion examples. Other reports in favor of this position are supported by mixed Kufan/Basran and Kufan/Medinese isnāds.

\footnotetext{
35 `Abd al-Razzāq, Muṣannaf, 2:88-93; Ibn Abī Shayba, Muṣannaf, k. al-ṣalāt 236, man kāna lā yajharu bi-bi-'smi Allāh al-Raḥmān al-Raḥīm, ed. J\&L, 2:367-71.

36`Abd al-Razzāq, Muṣannaf, 2:88; Ibn Abī Shayba, Muṣannaf 2:370.

${ }^{37}$ Ibn Abī Shayba, Mușannaf, 2:369.
} 
The evident pattern is for all-Meccan isnāds to support the position that one first recites bi- 'sm Allāh al-Rahmān al-Rahīm aloud, all-Basran isnāds to support the position that one begins with al-hamd lillāh, and all-Kufan isnāds to support the position that one first recites bi-'sm Allāh al-Raḥmān al-Rahìm to oneself. If we take these to be the positions of the respective regional schools, Meccan, Basran, and Kufan, contradictory reports and mixed isnāds are obviously explained by Joseph Schacht's model of inter-regional polemics. The Meccan position later became that of the Shāfìi school, the Basran position of the Māliki, and the Kufan position of the Hanafi. The only unusual feature of hadith concerning this topic is that Mālik expressly takes his evidence from a series of Basrans, not earlier Medinese, whereas Mālik normally supports his position by citing hadith from the Prophet and Companions with purely Medinese chains of transmission. ${ }^{38}$ Of significance here is that regional positions have been convincingly identified; also, that whereas Basran and Kufan Followers are quoted as espousing positions of their own, their Meccan and Medinese contemporaries are quoted only as relating what Companions and the Prophet said before them. The tradition (especially Māliki) tells us this is because Hijazis were more faithful to precedent than Iraqis. On Schacht's hypothesis, on the other hand, one infers that the record of Hijazi jurisprudence has a higher proportion of back projection.

A significant methodological question raised by Haider is how to identify an isnād that belongs entirely to one center. In his book, he apparently looks at transmitters in the whole second/eighth century. Elsewhere, however, Haider considers links from between 100 and 150 H. (roughly 718-67). ${ }^{39}$ This narrower range avoids the problem of traditionists who seem to relate hadith as completists, not advocates of a regional tradition; for example, the Wasiti

\footnotetext{
${ }^{38}$ See Haider, Origins, 61-6, for a review of Māliki rationalizations.

${ }^{39}$ Ibid., 80; private communication.
} 
Hushaym b. Bashīr (d. 183/799), al-Shāfi ${ }^{1}$ as he deliberately reviews the hadith his opponents cite, and `Abd al-Razzāq and Ibn Abī Shayba, who continually present hadith in favor of some position, then hadith in favor of the opposite. It has the disadvantage of not discriminating between Follower and Companion reports. At least on Schacht's model, there is some presumption that the former are earlier.

Behnam Sadeghi has stressed precisely the difference between mixed and single-region isnāds in "The Traveling Tradition Test: A Method for Dating Traditions." Sadeghi is largely concerned with Prophet hadith and offers arguments both for discrediting some on the ground of mixed isnāds and confirming others as genuinely going back at least to the first century H. One of Sadeghi's examples is the problem, which he calls archaic, of whether someone's ritual prayer is invalidated by the passage in front of him of a dog, an ass, or a woman. Sadeghi collects ten hadith reports that name all three, six of them with purely Basran isnāds; for example, Ibn Abī Shayba < Mu’tamir b. Sulaymān (Basran, d. 187/802-3) < Salm (b. Ab̄̄ al-Dhayyāl, Basran, fl. 2nd/8th cent.) < al-Ḥasan (Basran, d. 110/728): "Dogs, women, and asses cut off the ritual prayer." ${ }^{\prime 4}$ Variant doctrines, such as naming dogs alone or specifying menstruating women or black dogs, are consistently associated at some level with other cities especially, it seems, Mecca. Reports naming all three without qualification thus seem to enounce a distinctly Basran doctrine. It was not so regarded in the guild period. For example, the Egyptian Ḥanafi Badr al-Dīn al-`Aynī (d. 855/1451) states that, although the rule is now rejected by most jurisprudents, those who said dogs, asses, and women invalidate a ritual prayer were

\footnotetext{
${ }^{40}$ Sadeghi, “Traveling,” 214; Ibn Ab̄̄ Shayba, Muṣannaf, 2:144. Sadeghi cites Ibn Ab̄̄ Shayba, Muṣannaf, ed. Laḥhām, 1:315, substituting "Salm,” the name of a known transmitter from al-Ḥasan, for printed "Sālim.” Jum `a and Luḥaydān make the same correction, apparently with support from one of their manuscripts. The Laḥhām edition is merely a retyping of the 1960s Hyderabad edition with added mistakes and should no longer be cited.
} 
Anas, Makhūul, Abū 'l-Aḥwaṣ, al-Ḥasan, and 'Ikrima; that is, besides one Companion, Followers of Damascus, Kufa, Basra, and Medina. The example seems, then, to cast doubt on the wisdom of inferring prevalent doctrines from late lists of Followers who espoused them. Ibn Abī Shayba indeed quotes Makhūl al-Shāmī, for example, in favor of this doctrine but by a completely Basran isnād below him. ${ }^{41}$

Sadeghi's study is outstandingly thorough, based on a wider range of sources than either Dutton's or Haider's, as in drawing on Ahmad's Musnad. It helps him, among other things, to discredit a quotation of 'A' 'ishah with a Syrian isnād: “The Messenger of God said that nothing breaks the prayer of a Muslim but donkeys, unbelievers, dogs , and women. 'Ā'isha said, '[O] Messenger of God! We are joined with beasts. How awful!'” As Sadeghi says, the wording appears to have been fashioned precisely to answer the many reports by which 'A'isha rejects the rule. He might have cited, among others, Abū Dāwūd $<$ Musaddad (b. Musarhad, Basran, d. 228/843) < Yahyāa (b. Sa īd al-Qațtān, Basran, d. 198/813?) < `Ubayd Allāh (b. 'Umar, Medinese, d. 147/764-5?) < al-Qāsim (b. Muḥammad b. Ab̄̄ Bakr, Medinese, d. 101/719-20?) $<$ 'A'isha: "How bad of you to join us (as equals) to asses and dogs. I saw the Messenger of God pray when I was right before him. When he wished to prostrate himself, he touched my leg so I gathered it up and then he prostrated himself." ${ }^{\prime 2}$ However, the source he actually cites is `Abd al-Razzāq, quoting her without mention of the Prophet: "O people of Iraq, you have joined me (as an equal) to a dog or an ass. Nothing cuts off the ritual prayer, but be as careful as you can. ${ }^{, 43}$ Knowing the collections of Abū Dāwūd and others enables him to say that her rejection was widely reported. However, as with Yasin Dutton, it seems he did not urgently need to go

\footnotetext{
${ }^{41}$ Sadeghi, “Traveling,” 214, no. 7; Ibn Abī Shayba, Muṣannaf, 2:144.

${ }^{42}$ Abū Dāwūd, Sunan, k. al-ṣalāt 111, bāb man qāla al-mar'a lā taqța u 'l-ṣalāt, no. 712.

${ }^{43}$ Sadeghi, “Traveling,” 207fn., 217; ’Abd al-Razzāq, Muṣannaf, 2:30.
} 
beyond our best sources for eighth-century debates, `Abd al-Razzāq and Ibn Abī Shayba, at least to determine the Basran character of the rule about a dog, an ass, or a woman. What then of the thesis that Basra and Kufa were the earliest centers of legal controversy? Here, Ibn Abī Shayba is not much help, not documenting Kufan opposition for us. ${ }^{44}$ Neither is there evidence that the Basran rule enjoyed any significant later support in Medina.

\section{TWENTY-TWO OTHER CONTROVERSIES}

My present contribution to the discussion is a review of twenty-two other legal controversies for which Ibn Abī Shayba reviews in succession evidence for and against a proposed rule. My hypothesis that Kufa and Basra were the original centers of juridical controversy will be confirmed if it turns out that a majority of Followers in each of these two are regularly cited in support of opposing rules, with Medinese Companion hadith supporting the Basran position. The traditional characterization of Iraq and Medina as the original centers of juridical controversy will be confirmed if it turns out that a majority of Followers in both Kufa and Basra are regularly cited in support of one rule, opposed by a majority of Medinese Followers in support of an opposing one. If no particular pattern emerges, that will tend to support the null hypothesis that there were no regional schools, just individuals agreeing or disagreeing with others more or less at random. My summaries stress isnāds from one center, at least to near the end of the eighth century, ignoring most mixed isnāds.

\section{$\underline{\text { Kufa against Basra }}$}

\footnotetext{
${ }^{44}$ G. H. A. Juynboll identifies the Basran Qatāda as the originator of a Prophet hadith report naming dogs, asses, and women: Encyclopedia, 443. He assigns counter-hadith reports to the Kufan al-A`mash, the Medinese Mālik, and the Basran Shu'ba: Encyclopedia, 123, 315, 561.
} 
Whether the minor ritual ablution is required for qals (vomit that reaches the mouth but does not leave the body) (1:75-6). Kufan Follower hadith in favor, Basran against. The same from `Abd al-Razzāq, also two Meccan Follower reports in favor. ${ }^{45}$

Whether, in the ritual prayer, the hands should be raised to the shoulders or the ears (2:59-62). A Basran Follower report favors the shoulders, while the ears are favored by two Kufan Follower and two Prophet reports.

\section{$\underline{\text { One center divided }}$}

How often to wipe the head (1:29-31). Follower hadith for once all Kufan, for twice mixed but mainly Basran or Medinese, for three times solely and archaically Kufan.

Whether to perform multiple ritual prayers on one ablution (1:52-5). Kufan and Basran Follower hadith in favor, Basran only for a new ablution for each prayer.

Ritual ablution with a woman's leftover water (1:62-4). Kufan and Basran hadith in favor, Basran only against. `Abd al-Razzāq quotes a Meccan Follower and two Medinese Companion reports in favor, a Basran Follower and a Basran Companion hadith report against. ${ }^{46}$ Whether kissing calls for renewed ablutions (1:83-5). Kufan hadith on both sides, Basran in favor. `Abd al-Razzāq quotes Basran Follower reports on both sides, no Kufan opposed. ${ }^{47}$ More Kufan appeals to Hijazis, Companions, and the Prophet on the side of no ritual ablution for kissing, so this is probably the newer position. Mālik cites two Companions and one

\footnotetext{
45`Abd al-Razzāq, Mușannaf, 1:136-8.

${ }^{46}$ Ibid., 1:105-8.

${ }^{47}$ Ibid., 1:132-6.
} 
Follower in favor, all with purely Medinese isnāds. ${ }^{48}$ It is possible that these are what Kufan appeals to Hijazis, Companions, and the Prophet were opposing.

Whether eating food touched by fire calls for renewed ablutions (1:88-97). Basran Companion and Follower hadith on both sides, but only Basran hadith in favor, as opposed to multiple Kufan reports against, also a Medinese Prophet report and a Meccan Companion.

Whether the adhān and iqāma are required for women (2:40-2). Actually, no one is quoted as saying it is either required or forbidden. One Kufan Follower report and two Basran deny that it is obligatory, while one Kufan Companion report is a little more encouraging of it.

Whether to raise the hands only at the opening of the ritual prayer or at multiple points throughout (2:62-6). Two Kufan Prophet reports, seven Follower for raising the hands only once. Two Kufan Prophet reports, two Basran Companion, three Follower for raising hands repeatedly. `Abd al-Razzāq offers three Kufan Companion and one Follower report for raising the hands only once, confirming that this was the majority position in Kufa, three Meccan Follower reports for raising hands repeatedly. ${ }^{49}$

Whether to close the ritual prayer with one salutation or two (2:173-82). Strongly Kufan in favor of saluting twice, with no unmixed Basran isnāds on this side. More mixed in favor of once: two Kufan Follower reports but more usually some Basran links, including two Basran Follower reports, two Basran Companion, and one Basran Prophet.

Whether it is comely to develop a callus from frequent prostration (2:190-2). Kufan hadith on both sides, one Basran Companion report against.

\footnotetext{
${ }^{48}$ Mālik, Muwațta', rec. Yahyā, al-ṣalāt 24, al-wuḍū' min qublat al-rajul imra'atah, nos. 106-8; rec. Muṣ`ab, al-ṣalāt 16, al-wuḍ̄' ' min al-qubla, nos. 117-19. Al-Shāfi '̄ quotes the first Companion report from Mālik: Umm, $1: 121: 37$

49 `Abd al-Razzāq, Mușannaf, 2:67-74.
} 


\section{Both centers divided}

Whether to run the fingers through the beard in the course of the minor ritual ablution (1:24-8). Purely Kufan and Basran isnāds on both sides, but somewhat more Kufan support, Basran opposition.

Whether to wipe the turban (1:42-5). Kufan Follower hadith on both sides, Basran and Medinese for removing the turban, but Basran Companion and Prophet hadith on both sides. Presumably, preference for removing the turban, not just wiping it, grew across the eighth century. `Abd al-Razzāq offers no reports with Basran isnāds, but quotes Meccan Followers on both sides. ${ }^{50}$

Whether pissing requires washing the penis (1:100-2). Basran reports on both sides, likewise Kufan Companion reports, but three Kufan Follower reports in favor, suggesting an earlier majority in favor.

Whether the muezzin may speak in the course of his call to prayer (2:21-2). Basran and Kufan hadith on both sides, but more Basran Follower hadith for allowing speech, more Kufan against.

Whether a man may prostrate himself without removing his hands from his garment (2:115-18). Basran and Kufan Companion hadith on both sides, but Kufan Follower reports allow keeping the hands inside, Basran and Medinese Follower reports require withdrawing them.

Whether a man may prostrate himself without removing his turban (so that his forehead does not directly touch the ground) (2:118-21). Basran and Kufan Companion and Follower reports on both sides.

\section{Other combinations}

\footnotetext{
${ }^{50}$ Ibid., 1:187-90.
} 
For performing the minor ritual ablution in threes or a smaller number (1:16-22). No Follower hadith. Appears to be an internal Kufan controversy.

Whether eating camel flesh calls for renewed ablutions (1:87-8). Largely Kufan on both sides, but Follower and Companion examples oppose requiring the minor ritual ablution, whereas there are Prophetic as well in favor of it, also more Basran involvement, so presumably the more lenient position is the older Kufan one.

Whether the muezzin must be in a state of ritual purity (2:19-20). Mixed isnāds from Medina and Mecca in favour, Kufan and Basran hadith against. But whereas `Abd al-Razzāq quotes the same report of one Kufan Follower, Ibrāhīm, he has Meccan and Basran Follower reports in favor of requiring ritual purity. ${ }^{51}$

Whether the prostration requires touching the nose to the ground as well as the forehead (2:109-11). Kufan Follower hadith on both sides. `Abd al-Razzāq reports Kufan Follower hadith in favor, also Meccan and a Medinese Companion report. ${ }^{52}$

Whether one may prostrate oneself on a pillow or other support (2:127-8). Three Basran Companion reports in favor, one Basran Follower report against.

Twenty-two is a small sample size, chosen for no better reason than how much time I found this summer to look up names in $i s n \bar{a} d \mathrm{~s}$. Also, the controversies summarized here all have to do with the ritual law, not interpersonal relations (mu 'ämala $\bar{t}$ ), again for no better reason than convenience, unless ritual is an area where public opinion must have been peculiarly effective in producing regional uniformity. (In the guild period, different neighborhoods would observe their peculiar ritual forms, as the tenth-century traveler al-Maqdisī observes; but even then, there

\footnotetext{
${ }^{51}$ Ibid., 1:465-6.

${ }^{52}$ Ibid., 2:179-83.
} 
might be odd combinations of doctrines from different schools. ${ }^{53}$ ) Still, I predict that further research will tend to confirm the patterns evident here. First, Basra and Kufa are by far the bestrepresented centers when it comes to hadith with unmixed isnāds. They were clearly early centers of jurisprudence. Ibn Abī Shayba, at least, gives no impression that the principal antagonists were the jurisprudents of Kufa and Medina, respectively. To be sure, he was Kufan, himself, and took very little hadith from Meccan or Medinese shaykhs (about 3 percent of all items in the Mușannaf, almost all the rest from shaykhs of Kufa - two-thirds of the total - , Basra, Wasit, or Baghdad). Still, it appears that, thanks to Ibn Abī Shayba, Basran doctrine can be reconstructed in much more detail than Schacht thought possible. ${ }^{54}$ `Abd al-Razzāq offers supplementary reports of Follower opinion in Mecca and Medina as well as, less often, Kufa and Basra. Seldom does he alter the picture of regional doctrines from Ibn Abī Shayba - only once, really, in this sample of twenty-two controversies, where he would shift the question of whether the muezzin may be in a state of ritual impurity from the category of Kufan-Basran agreement to the category of unity in one center (Kufa) but division in the other (Basra).

Secondly, the largest category comprises apparent unity in one center, division in the other. The next largest category comprises disagreement in both centers. On only one question of the 22 , whether the muezzin needs to be ritually pure, does there seem to be a split between Iraqis on one side, Hijazis on the other — what ought to be the usual case if Iraq and Medina had been the chief rival centers. Usually, it is possible to infer which position enjoyed majority

\footnotetext{
${ }^{53}$ E.g., Maqdisī, Descriptio, 180 (the appearance of Shāfi ' i predominance in Syria belied by their preferring not to pronounce the basmala aloud or to add the qunüt outside the second half of Ramaḍann), 323 (one of the mosques of Marw Shāfi 'i except that they pronounce the iqāma there in twos).

54 “Although occasional references to the Basrians are not lacking, little is known about their doctrine in detail, and our knowledge of the ancient Iraqians is mainly confined to the Kufians": Schacht, Origins, 8.
} 
support in each center, as with whether to run the fingers through the beard; but the case is admittedly never strong. A minority position in the time of the Followers may have become the majority position later on, likely to be supported by Companion and Prophet hadith as they became winning arguments. Comparison between the doctrines of regional and guild schools will provide abundant examples.

Thirdly, citing authorities from a rival center seems to have been very common in the course of eighth-century controversy. I have examined almost 400 hadith reports from Ibn Abī Shayba concerning these twenty-two other controversies. They are evenly divided between mixed and single-region isnāds. I have, of course, systematically downplayed mixed-isnād reports in identifying regional positions. The great ninth-century collectors of Prophet hadith seem also to have downplayed mixed-isnād reports. Working mainly from biographical dictionaries although also indirectly from Ahmad's Musnad, Scott C. Lucas has identified the generation of traditionists who died 120-50 (738-67) as specialists in the hadith of "a particular

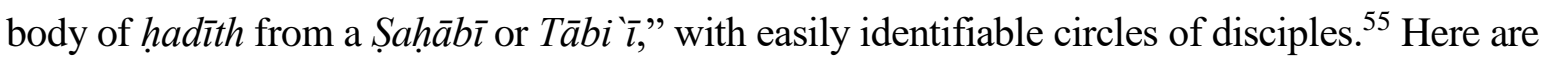
some figures I have assembled from a randomly-chosen sample of 246 hadith reports in the Sahịh of al-Bukhārī, showing transmission roughly from the earlier eighth century (Follower level) to the middle or later:

$$
\begin{aligned}
& \text { Basra } \rightarrow \text { Basra } 46 \\
& \text { Basra } \rightarrow \text { Kufa } 4 \\
& \text { Basra } \rightarrow \text { elsewhere } 4
\end{aligned}
$$

Kufa $\rightarrow$ Basra 13

\footnotetext{
${ }^{55}$ Lucas, Constructive, 341.
} 
Kufa $\rightarrow$ Kufa 47

Kufa $\rightarrow$ elsewhere 1

Mecca $\rightarrow$ Basra 4

Mecca $\rightarrow$ Mecca 4

Mecca $\rightarrow$ elsewhere 2

Medina $\rightarrow$ Basra 13

Medina $\rightarrow$ Egypt 9

Medina $\rightarrow$ Kufa 17

Medina $\rightarrow$ Medina 61

Medina $\rightarrow$ Syria 7

Medina $\rightarrow$ elsewhere 5

Clearly, al-Bukhārī thought highly of hadith that (apparently) circulated in Medina in the first half of the second century $\mathrm{H}$. He also seems to have eschewed hadith with mixed isnāds far more than Ibn Abī Shayba. Behnam Sadeghi has pointed out to me that one strong reason for Ibn Abī Shayba to have more mixed isnāds is that, having collected so little from Hijazi shaykhs, most traditions originating in the Hijaz could reach him only through mixed isnāds. But Bukhārī also took more material from Kufan shaykhs than Medinese, and presumably heard much Kufan/Medinese hadith in Kufa, so this category still seems underrepresented in the Sahīh. (By my calculations, Bukhārī collected about 11 percent of the Șaḥịh from Kufan shaykhs, 6 percent from Medinese. The comparison would admittedly be easier if we could look at his Kitāb 
al-Sunan fi 'l-fiqh, which presumably comprised quantities of Companion and Follower opinions. ${ }^{56}$ )

At the level of the Followers, I fear it is Medinese doctrine that will be the hardest to reconstruct in detail. Ibn Abi Shayba's Mușannaf provides by far our best documentation of eighth-century legal controversy, comprising almost twice as many items as `Abd al-Razzāq’s Muṣannaf and over a dozen times as many as Mālik's Muwaț̣a' ${ }^{57}$ However, Ibn Abī Shayba is evidently best for controversy in Kufa and Basra. For only a few of the twenty-two questions reviewed here does the Muwatta' offer anything. Moreover, Mālik's Muwatta' usually takes an openly polemical approach, seldom documenting disagreement with its own position. This limits its usefulness for making out the history of Medinese jurisprudence. One example has been noted already, as to whether kissing calls for renewed ablutions. Mālik offers Medinese reports in favor of what seems in the Musannaf to be the Basran position. Another is whether one may merely wipe the turban without removing it. Some Basrans seem to have taken a permissive stance, citing Companions and the Prophet in their favor, but Basran Followers are quoted against this position. Mālik also is against it, but offers only his unsupported opinion, telling us nothing of earlier Medinese controversy. ${ }^{58}$ It is usually very hard to tell whether lack of information on Medinese positions in the generation before Mālik means that they were not discussing a particular position, they were discussing it but Mālik prefers weightier appeals to Companions and the Prophet, or they were discussing it but advocated different rules from what Mālik believes in.

\footnotetext{
${ }^{56}$ Listed among his works by Ibn al-Nadīm, Fihrist, fann 6, maqāla 6.

${ }^{57}$ For more on Ibn Abī Shayba and his Mușannaf, see Lucas, "Where?”

${ }^{58}$ Mālik, Muwațta', rec. Yaḥyā, al-ṣalāt 15, mā jā'a fi 'l-masḥ bi- 'l-ra's wa-l-udhnayn, no. 77; rec. Muṣ`ab, al-șalāt 7, bāb mā jā'a fì masḥ bi-'l-ra's, no. 85 .
} 
Of the controversies reviewed above, Mālik offers the most on whether eating food touched by fire calls for renewed ablutions, a position supported only in Basra, not Kufa, to judge by Ibn Abī Shayba's presentation. Mālik presents three Prophet and six Companion reports against. The last of them expressly repudiates Iraqi practice: that Anas b. Mālik, on coming from Iraq (he was known for settling in Basra), ate some food affected by fire with fellow Companions Abū Ṭalḥa al-Anșārī and Ubayy b. Ka`b. He then performed the minor ritual ablution but they protested: "What is this, Anas - (something) Iraqi?" Anas expressed remorse: "Would that I had not done this." 59 This report of Mālik's reads like a parody of Ibn Abī Shayba's, with a Basran isnād, that Anas b. Mālik was indignant because al-Hajjāj and his courtiers had eaten, then prayed without first performing the minor ritual ablution. ${ }^{60}$ `Abd al-Razzāq is a little helpful, here, providing three Medinese Prophet reports, one Meccan/Medinese Prophet report, and four Medinese Companion reports in favor of the ritual ablution, along with an unsupported report (i.e., without isnād) that the Basran Ma`mar (d. 153/770?) and the Medinese al-Zuhrī (d. 124/741-2?) would renew their ablutions if they had eaten food touched by fire: this confirms that there was some Medinese opinion in favor of the ritual ablution (in line with Basran Follower opinion). Indeed, Mālik is presumably arguing

\footnotetext{
${ }^{59}$ Mālik, Muwațta', rec. Yahyá, șalāt 13, tark al-wuḍ̄' 'mimmā massat al-nār, nos 54-62; rec. Muṣ`ab, șalāt 5, bāb al-wuḍū' mimmā massat al-nār, nos. 62-70.

${ }^{60}$ Ibn Abī Shayba, Mușannaf, k. al-țahāra 62, man kāna yarā 'l-wuḍū' mimmā ghayyarat al-nār, ed. J\&L, 1:95, no. 560; also `Abd al-Razzāq, Mușannaf, 1:173-4, variant at 1:170. For Anas’ Basran connection, see for example Ibn Sa`d, Biographien, 7/1:10-16 7:17-26, esp. 16 25-6.
} 
against such fellow Medinese, not Basrans, for only Medinese would be hurt by the allegation that their doctrine was recognizably Iraqi. ${ }^{61}$

This review of twenty-two other controversies does, then, confirm what others have observed of the Muwatta', such as Patricia Crone: “on first reading, this book conjures up an inward-turned provincial society abiding by its local ways in more or less complete ignorance of developments outside ... . Yet this impression of patriarchal innocence is totally spurious." ${ }^{\prime 62}$ The Muwatta' can be relied on to tell us Mālik's opinion and sometimes evidence he thought favorable but not very well unacknowledged influences, such as debates in Iraq, or what other Medinese thought; in particular, therefore, what doctrines distinguished the Medinese school in the earlier eighth century.

Finally, then, because of sketchy information about Medina before the mid-eighth century, I conclude from my review of 22 other controversies that, although the thesis of characteristic disagreement between Kufa and Basra is confirmed, there is no strong evidence here either confirming or disconfirming systematic Medinese borrowing from Basra. In the sample of 22 controversies, Mālik seems as likely to back an earlier Kufan as an earlier Basran view. This inconclusiveness is disappointing. Although admitting that my search of the evidence has been far less thorough, I take some small comfort in the precedent of a recent article by Patricia Crone, "Quraysh and the Roman Army: Making Sense of the Meccan Leather Trade."

\footnotetext{
${ }^{61} \mathrm{Cf}$. Katz, who tentatively concludes that renewing ritual ablutions after eating food touched by fire was originally the practice of "ascetic circles in Basra," taken up, fitted with Prophet hadith, and unsuccessfully promoted by the caliph `Umar b. `Abd al-`Azīz: Body, 101-23.

${ }^{62}$ Crone, "Jāhilī," 196-7.
} 
She concludes, "Did Quraysh make their wealth by organizing supplies to the Roman army? As things stand, a case can be made for it, but not proved." ${ }^{\text {,63 }}$

\section{Bibliography}

`Abd al-Razzāq. Al-Muṣannaf. Ed. Ḥabīb al-Raḥmān al-A`ẓamī. Johannesburg: Majlis Ilmi, 1390-2/1970-2.

`Aynī, al-. Al-Bināya sharh al-Hidāya. Ed. Muhammad b. `Umar Nāṣir al-Islām al-Rāmafūrī. Lucknow: Nawakishawr, 1293. Reprinted Beirut: Dār al-Fikr, 1400-1/1980-1.

Berg, Herbert. The Development of Exegesis in Early Islam. Curzon Studies in the Qur'ān. Richmond, Surrey: Curzon, 2000.

Brunschvig, Robert. "Polémiques médiévales autour du rite de Mālik.” Al-Andalus 15 (1950): 377-413.

Cook, Michael. "The opponents of the writing of tradition in early Islam." Arabica 44 (1997): 437-530.

Crone, Patricia. "Jāhilī and Jewish Law: the qasāma." Jerusalem Studies in Arabic and Islam, 4 (1984), 153-201.

—. "Quraysh and the Roman Army: Making Sense of the Meccan Leather Trade." BSOAS 70 (2007): 63-88.

- Roman, Provincial, and Islamic Law. Cambridge: University Press, 1987.

Dutton, Yasin. “"An Innovation from the Time of the Banī Hāshim’: Some Reflections on the tastim at the End of the Prayer." Journal of Islamic Studies 16 (2005): 147-76.

Fasawī, al-. Kitāb al-Ma`rifa wa-l-tārīkh. 3rd ed. Ed. Akram Diyā’ al-`Umarī. Medina: Maktabat al-Dār, 1410/1989.

\footnotetext{
${ }^{63}$ Crone, "Quraysh,” 86.
} 
Haider, Najam I. The Origins of the Shī`a. Cambridge: University Press, 2011.

—_. “To Basmalah or Not to Basmalah?” In Prosopography: Approaches and Applications, Ed. K. S. B. Keats-Rohan, 459-98. Oxford: Unit for Prosopographical Research, Linacre College, 2007.

Hallaq, Wael B. "From Regional to Personal Schools of Law? A Reevaluation." Islamic Law and Society 8 (2001): 1-26.

Hurvitz, Nimrod. "Schools of Law and Historical Context: Re-examining the Formation of the Hanbali madhhab.” Islamic Law and Society 7 (2000): 37-64.

Ibn Abī Shayba, Abū Bakr. Al-Muṣannaf. Ed. Muḥammad `Abdallāh al-Jum`a and Muḥammad Ibrāhīm al-Luḥaydān. Riyadh: Maktabat al-Rushd, 1425/2004. Also ed. Sa `ìd al-Laḥhām. Beirut: Dār al-Fikr, 1409/1989.

Ibn al-Muqaffa'. Al-Risāla fì 'l-ṣaḥāba. In Āthār Ibn al-Muqaffa', ed. 'Umar Abū 'l-Nașr, 345-61. Beirut: Dār Maktabat al-Ḥayāt, 1966.

Ibn al-Nadīm. Kitâb al-Fihrist. Ed. Gustav Flügel, with Johannes Roedigger and August Mueller. Leipzig: F. C. W. Vogel, 1872.

Ibn Sa`d. Biographien. Ed. Eduard Sachau et al. Leiden: E. J. Brill, 1904-40. (K. al-Ṭabaqāt al-kabīr.) Also reprinted without apparatus as al-Tabaqāt al-kubrāa. Beirut: Dār Șādir, 1957-68. References to latter edition in italic.

—. Al-Ṭabaqāt al-kubrā: al-qism al-mutammim li-tābi `ò ahl al-Madīna wa-man ba`dahum, min rub`al-țabaqa al-thālitha ilā muntaṣaf al-țabaqa al-sādisa. Ed. Ziyād Muḥammad Manșūr. Medina: al-Jāmi`a al-Islāmiyya and al-Majlis al-`Ilmīi, 1403/1983. Jeffery, Arthur. Materials for the History of the Text of the Qur'ān. Leiden: E. J. Brill, 1937.

Juynboll, G. H. A. Encyclopedia of Canonical Hadīth. Leiden: Brill, 2007.

—_. "Some Notes on Islam's First fuqahā'.” Arabica 39 (1992): 287-314. 
Katz, Marion Holmes. Body of Text: The Emergence of the Sunnī Law of Ritual Purity. Albany: State University of New York Press, 2002.

Lucas, Scott C. Constructive Critics, Hadīth Literature, and the Articulation of Sunnī Islam: The Legacy of the Generation of Ibn Sa`d, Ibn Ma`in, and Ibn Hanbal. Leiden: Brill, 2004.

—. "Where Are the Legal Hadīth? A Study of the Muṣannaf of Ibn Abī Shayba." Islamic Law and Society 15 (2008): 283-314.

Makdisi, George. "Tabaqāt-Biography: Law and Orthodoxy in Classical Islam.” Islamic Studies (Islamabad) 32 (1993): 371-96.

Mālik. Al-Muwațta’. Recension of Yahyāā. Ed. Bashshār `Awwād Ma rūf. Beirut: Dār al-Gharb al-Islāmī, 1417/1997. Recension of Abū Muṣ `ab al-Zuhrī. Ed. Bashshār `Awwād Ma’rūf and Maḥmūd Muḥammad Khalīl. Beirut: Mu’assasat al-Risāla, 1413/1993.

Maqdis̄̄ (Muqaddasī), al-. Descriptio imperii moslemici. 2nd ed. Ed. M. J. De Goeje. Leiden: E. J. Brill, 1906. (Aḩsan al-taqāsìm fì ma 'rifat al-aqālīm.)

Mardāwī, 'Alī b. Sulaymān al-. Al-Inșāfffì ma 'rifat al-rājiḥ min al-khilāf 'alāa madhhab al-imām Aḥmad b. Hanbal. Ed. Muḥammad Ḥāmid al-Fiqī. Cairo: Maṭba`at al-Sunna al-Muḥammadiyya, 1955-8. Reprinted Dār Iḥyā’ al-Turāth al-`Arabī, 1419/1998.

Melchert, Christopher. "The Concluding Salutation in Islamic Ritual Prayer.” Le Muséon 114 (2001): 389-406.

—. "The Formation of the Sunnī Schools of Law." The Formation of Islamic Law, ed. Wael B. Hallaq, 351-66. Aldershot: Ashgate, 2004.

—. "The History of the Judicial Oath in Islamic Law." In Oralité et lien social au Moyen Âge (Occident, Byzance, Islam), ed. Marie-France Auzépy and Guillaume SaintGuillain, 309-26. Paris: ACHCByz, 2008. 
—_. "The Life and Works of al-Nasā'̄̄." Forthcoming in Journal of Semitic Studies.

—_. "The Muṣannaf of Ibn Abī Shaybah.” Paper presented to the American Oriental Society, Philadelphia, March 2005.

—_. "Public Baths in Islamic Law." Forthcoming in a collection of essays ed. Thibaud Fournet, et al. ['Public Baths in Islamic Law'. Pages 1001-10 in 25 siècles de bain collectif en Orient: Proche-Orient, Égypte et péninsule Arabique. Actes du $3^{e}$ colloque international Balnéorient, organisé par l'Institut français du Proche-Orient et la Direction Générale des Antiquités et des Musées de Syrie (Damas-Syrie/2-6. nov. 2009). Edited by Marie-Françoise Boussec, Sylvie Denoix, Thibaud Fournet, \& Bérangère Redon. Études urbaines 9 and PIFD 282. Cairo: Institut français d'archéologie orientale, 2014]

—. "Whether to Keep Women Out of the Mosque: A Survey of Medieval Islamic Law." In Authority, Privacy and Public Order in Islam: Proceedings of the $22^{\text {nd }}$ Congress of l'Union Européenne des Arabisants et Islamisants, edited by B. Michalak-Pikulska and A. Pikulski, 59-69. Leuven: Peeters, 2006.

Motzki, Harald. "Dating Muslim Traditions: A Survey,” Arabica 52 (2005): 204-53.

Nasā'̄i, al-. Tasmiyat fuqahā' al-amșār. In Majmū'at rasā'il fì 'ulūm al-ḥadìth, edited by Șubḥ̄ al-Badrī al-Sāmarrā’’̄ , 7-10. Medina: Muḥammad `Abd al-Muḥsin, 1389/1969. Also in Majmū'at rasā'il fì 'ulūm al-ḥadīth, ed. Nașr Abū 'Ațāyā and Muṣtafā Abū Sulaymān al-Nadwī, 19-44. Beirut: Dār al-Kutub al- 'Tlmiyya, 1413/1993. Reference to latter edition in italic.

Sadeghi, Behnam. "The Traveling Tradition Test: A Method for Dating Traditions.” Der Islam 85 (2008): 203-42.

Schacht, Joseph. The Origins of Muhammadan Jurisprudence. Oxford: Clarendon Press, 1950. 
Shāfi '`, al-. Ikhtilāf al-hadìth. In margin of al-Umm (Būlāq) 7:2-413; vol. 10 of al-Umm (ed. `Abd al-Muțtalib).

—. Kitāa al-Umm. Ed. Shihāb al-Dīn Aḥmad al-Ḥusaynī. Būlāq: al-Maṭba`a al-Kubrā al-Amīriyya, 1321-5. Reprinted Cairo: Kitāb al-Sha`b, 1388/1968. Also ed. Rif at Fawzī `Abd al-Mutțalib. Al-Manșūrah: Dār al-Wafā’, 1422/2001; 2nd printing 1425/2004. References to latter edition in italic.

Van Ess, Josef. Zwischen Hadīt und Theologie: Studien zum Entstehen prädestinatianischer Überlieferung. Berlin: Walter de Gruyter, 1975.

Yahia, Mohyddin. Šăfi ì et les deux sources de la loi islamique. Turnhout, Belgium: Brepols, 2009. 